UCRL-JC-133137

PREPRINT

\title{
Influence of Severe Plastic Deformation on the Structure and Properties of Ultrahigh-Carbon Steel Wire
}

Donald R. Lesuer

Chol K. Syn

Oleg D. Sherby

This paper was prepared for submittal to the

NATO Advanced Research Workshop

Investigations and Applications of Severe Plastic Deformation

Moscow, Russia

August 2-7, 1999

July 1999

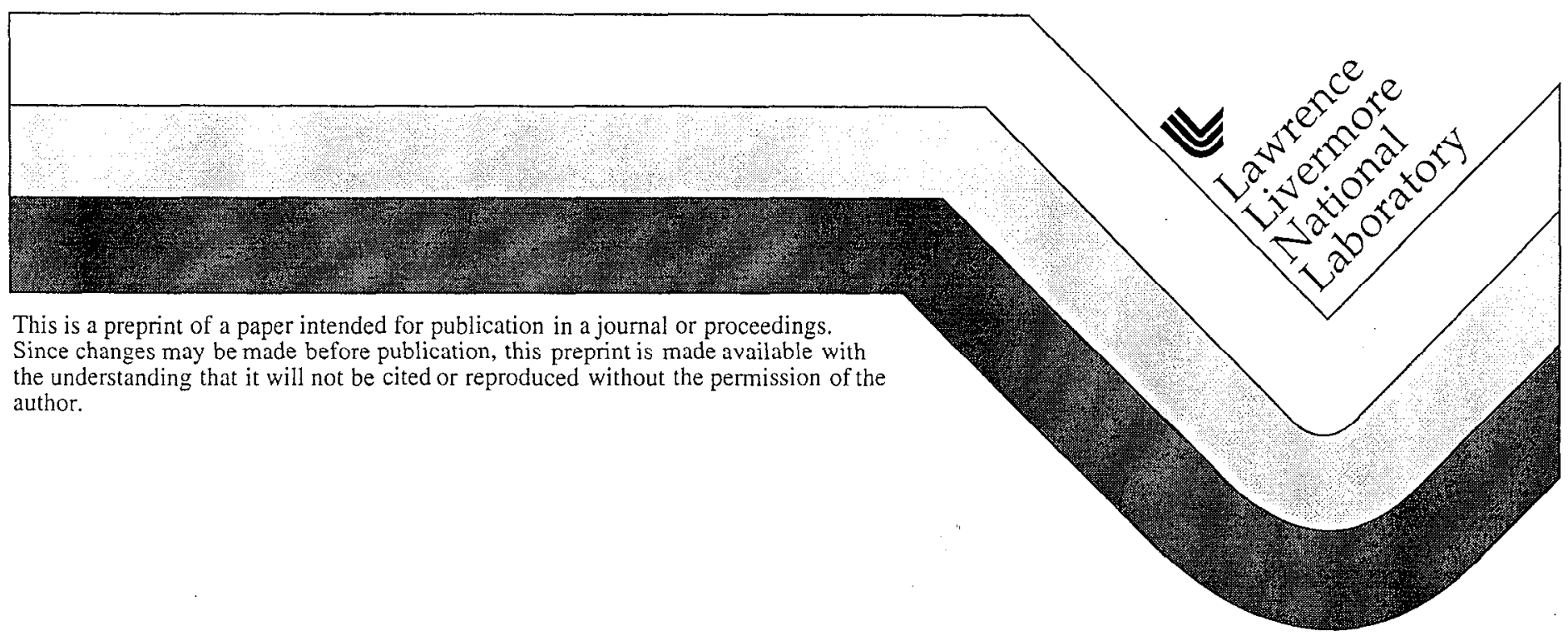




\section{DISCLAIMER}

This document was prepared as an account of work sponsored by an agency of the United States Government. Neither the United States Government nor the University of California nor any of their employees, makes any warranty, express or implied, or assumes any legal liability or responsibility for the accuracy, completeness, or usefulness of any information, apparatus, product, or process

disclosed, or represents that its use would not infringe privately owned rights. Reference herein to any specific commercial product, process, or service by trade name, trademark, manufacturer, or otherwise, does not necessarily constitute or imply its endorsement, recommendation, or favoring by the United States Government or the University of California. The views and opinions of authors expressed herein do not necessarily state or reflect those of the United States Government or the University of California, and shall not be used for advertising or product endorsement purposes. 


\title{
INFLUENCE OF SEVERE PLASTIC DEFORMATION ON THE STRUCTURE AND PROPERTIES OF ULTRAHIGH-CARBON STEEL WIRE
}

\author{
Donald R. Lesuer*, Chol K. Syn* and Oleg D. Sherby**, \\ * Lawrence Livermore National Laboratory, Livermore, CA 94551 \\ ** Stanford University, Stanford, CA 94305
}

\begin{abstract}
Ultrahigh-carbon steel wire can achieve very high strength after severe plastic deformation, because of the fine, stable substructures produce. Tensile strengths approaching $6000 \mathrm{MPa}$ are predicted for UHCS containing $1.8 \% \mathrm{C}$. This paper discusses the microstructural evolution during drawing of UHCS wire, the resulting strength produced and the factors influencing fracture. Drawing produces considerable alignment of the pearlite plates. Dislocation cells develop within the ferrite plates and, with increasing strain, the size normal to the axis $(\lambda)$ decreases. These dislocation cells resist dynamic recovery during wire drawing and thus extremely fine substructures can be developed $(\lambda<10 \mathrm{~nm})$. Increasing the carbon content reduces the mean free ferrite path in the as-patented wire and the cell size developed during drawing. For UHCS, the strength varies as $\lambda^{-5}$. Fracture of these steels was found to be a function of carbide size and composition. The influence of processing and composition on achieving high strength in these wires during severe plastic deformation is discussed.
\end{abstract}




\section{$\underline{\text { Introduction }}$}

Extensive plastic deformation resulting from wire drawing is commonly used to produce steel wires with high strengths. Typically these steels are eutectoid and hypereutectoid steels and drawing strains up to 4 are used during processing. At Lawrence Livermore National Laboratory, we have been studying the processing, structure and properties of steels with substantially higher carbon content. These steels are called ultrahigh-carbon steels (UHCSs) and typically contain 1 to $2.1 \% \mathrm{C}$ (1). The potential for increasing the strength of wires is illustrated in Fig. 1, which shows wire strength as a function of carbon content. The wire diameter $(0.28 \mathrm{~mm})$ and the amount of cold work is constant for all data points given as solid circles. The UHCSs are projected to have wire strengths in excess of $4000 \mathrm{MPa}$. These ultrahigh strength UHCS wires are expected to be significantly stronger than the $3400 \mathrm{MPa}$ wire currently used in premium tires. At $1.8 \% \mathrm{C}$, the UHCS wires are projected to have a strength approaching $6000 \mathrm{MPa}$. This paper discusses the microstructural evolution during drawing of UHCS wire, the resulting strength produced and the factors influencing fracture.

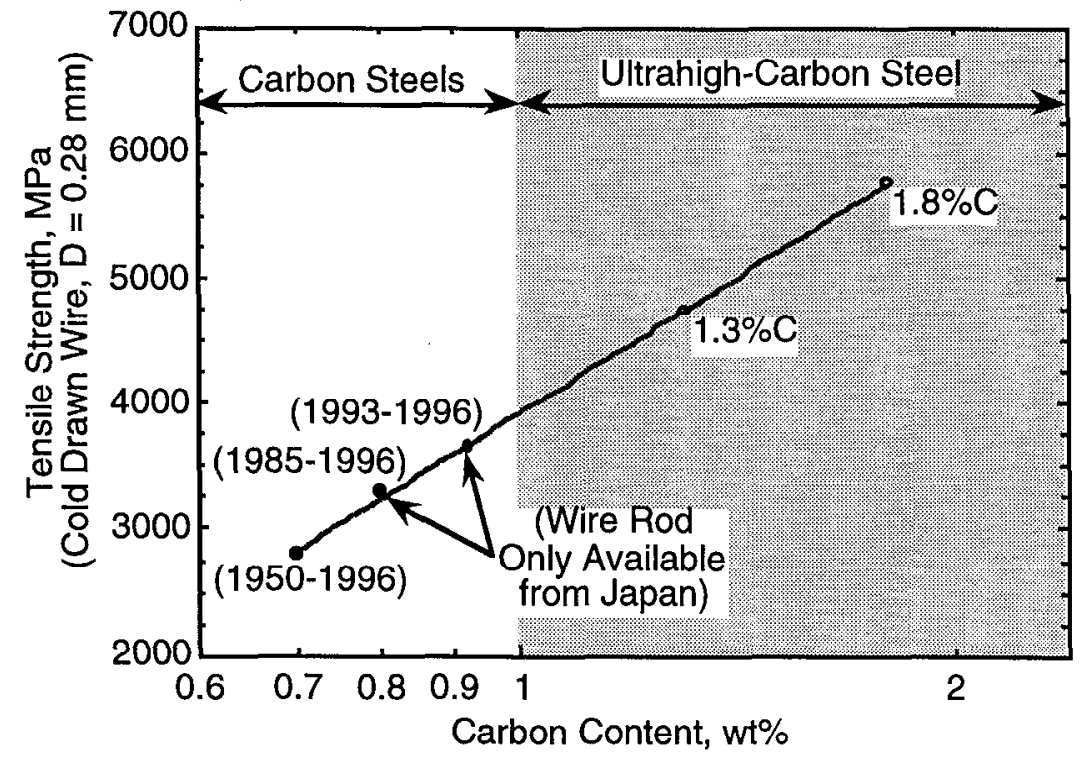

Fig. 1. Influence of carbon content on the strength of cold drawn steel wire. Current premium radial tires use high carbon steel wire with a strength of $3400 \mathrm{MPa}$. The projected strengths for ultrahigh carbon steels containing $1.3 \%$ and $1.8 \% \mathrm{C}$ are shown in the figure by the open circle symbols.

Processing and microstructural evolution

Processing before wire drawing. Achieving high strength and good ductility in UHCS requires breaking up the deleterious pro-eutectoid carbide network and developing ultra-fine carbides in pearlitic form. The formation of this pro-eutectoid carbide network can be influenced by composition, control over phase transformations and thermo-mechanical processing. Ochiai and his co-workers $(2,3,4,5)$ have investigated the influence of composition and cooling rate during patenting on the formation of a proeutectoid carbide network. Patenting involves rapid heating to austenite followed by rapid transformation to a fully pearlitic structure. Alloying additions that were found to inhibit the formation of a network include $\mathrm{Si}$ and Co. In the cooling rate studies, the tendency to form a proeutectoid carbide network was studied in a $0.2 \mathrm{Si}-0.5 \mathrm{Mn}$ steel as a function of carbon content and cooling rate. Higher cooling rates tend to suppress the formation of a network. In addition, as the carbon concentration in a hypereutectoid steel is increased, faster 
cooling rates are required to obtain pearlitic structures without a network. In this study, most of the cooling rates were achieved by lead patenting. The authors concluded that hypereutectoid steels with carbon content up to $1.10 \%$ could be patented to obtain a network-free microstructure using commercially-available cooling equipment which can achieve cooling rates of $10-15^{\circ} \mathrm{C} / \mathrm{s}$.

Microstructural evolution during wire drawing. Several investigators have studied the evolution of microstructure during drawing of mildly hypereutectoid steels $(6,7,8)$ and iron (9). The starting microstructure for wire drawing of eutectoid and hypereutectoid steels is fine pearlite with randomly oriented lamellae. The fine pearlite results from a patenting heat treatment. The mean free ferrite path in a eutectoid steel after patenting is typically $70 \mathrm{~nm}$. Increasing the carbon content will decrease the mean free ferrite path.

The evolution of this microstructure during wire drawing is shown schematically in Fig. 2. Drawing produces considerable alignment of the pearlite plates parallel to the drawing direction and reduction in the mean free ferrite path. The ferrite also develops a $<110>$ wire texture typical for BCC metals. Throughout the wire drawing process, the carbide plates deform to strains comparable to the ferrite plates and the carbide plates are also observed to fracture. Recent work has also shown that partial dissolution of the cementite phase can occur during severe plastic deformation of pearlitic steels(10). Dense dislocation tangles form in the ferrite and, at small drawing strains (approximately .25), dislocation cell walls form. These cell walls contain fragmented carbide particles. Transmission electron microscopy studies reveal that very few dislocations are found within the cells and a high dislocation density is found in the cell walls. With continuing deformation, these cells become thinner and resist extensive dynamic recovery. Embury et al. (7) have shown that the thickness of the cells scales as the diameter of the wire. The result is the development of a fine, stable substructure with very fine cell dimensions normal to the wire axis (e.g. $<10 \mathrm{~nm}$ ).

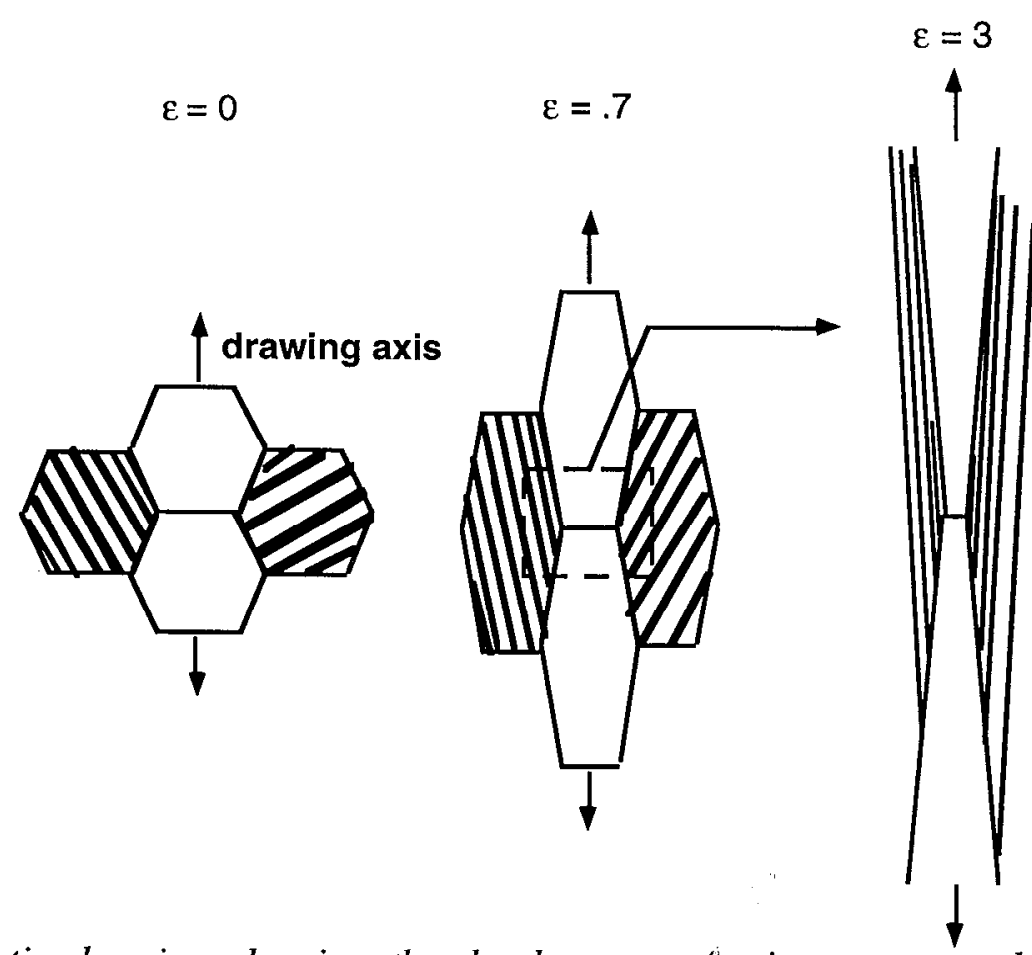

Fig. 2. Schematic drawing showing the development of microstructure during drawing of eutectoid composition steel. Typical drawing strains are indicated in the figure. 
Properties and Strengthening Mechanisms

The dominant deformation resistance in UHCS wire depends on the structure and substructure developed during processing. Previous studies of eutectoid and hypereutectoid steels $(11,12)$ with pearlitic microstructures have shown that, in the absence of severe plastic deformation, the yield strength is derived from hardening contributions associated with pearlite colony size, interlamellar carbide spacing and solute additions. The pearlite colony size and the interlamellar carbide spacing represent the dimensions of microstructural features that impose barriers to dislocation motion. These strengthening mechanisms contribute to the yield strength in an additive manner and, for eutectoid and hypereutectoid steels, the following equation has been derived.

$$
\sigma_{\mathrm{y}}=\left(\sigma_{\mathrm{o}}\right)_{\mathrm{ss}}+145\left(\mathrm{D}_{s}^{*}\right)^{-1 / 2}+460 \mathrm{~L}^{-1 / 2}
$$

where $\sigma_{\mathrm{y}}$ is the yield strength, $\left(\sigma_{\mathrm{o}}\right)_{s \mathrm{~s}}$ is the resistance to dislocation motion resulting from solid solution atoms, $\left(\mathrm{D}_{s}^{*}\right)^{-1 / 2}$ is the carbide spacing (interlamellar spacing or particle spacing) and $\mathrm{L}$ is the ferrite grain size or pearlite colony size.

After severe plastic deformation, additional strengthening mechanism(s) are introduced. A number of investigators have studied the increase in strength that results from cold drawing of eutectoid and hypereutectoid steel wires $(3,6,13,14,15,16,17)$. Most of these studies have reported strength as a function of wire diameter. Data from seven such materials are shown in Fig. 3. Five of these materials are hypereutectoid composition wires and two of the materials are eutectoid composition wire (piano wire and the data of Kim and Shemenski). The starting strength in all these studies is derived from a fully pearlitic microstructure produced as a result of a patenting treatment. The strengthening produced by these microstructures represents an important starting point for the very high strengths typically observed in severely drawn wire. The influence of cold wire drawing on the strength of hypereutectoid steels can be understood through further analysis of the data in Fig. 3. The increase in strength resulting from cold wire drawing was calculated as a function of drawing strain by subtracting the strength in the patented condition from the strength of the wire in the cold-drawn condition. Results are shown in Fig. 4 for three hypereutectoid steels with similar compositions. These materials had different aspatented strengths and different starting diameters. The results fall on a common curve suggesting that a common mechanism is responsible for the increase in strength by wire drawing. It is also important to recognize that, even after a drawing strain of 4 , the strength of the wire is continuing to increase with increasing strain. These high work hardening rates at high strains are in contrast to the work hardening rates in FCC metals (7), which are substantially lower. The reduced work hardening rates in FCC metals at large strains result from more extensive dynamic recovery and thus a slower rate of reduction in the size of dislocation substructure relative to iron. 

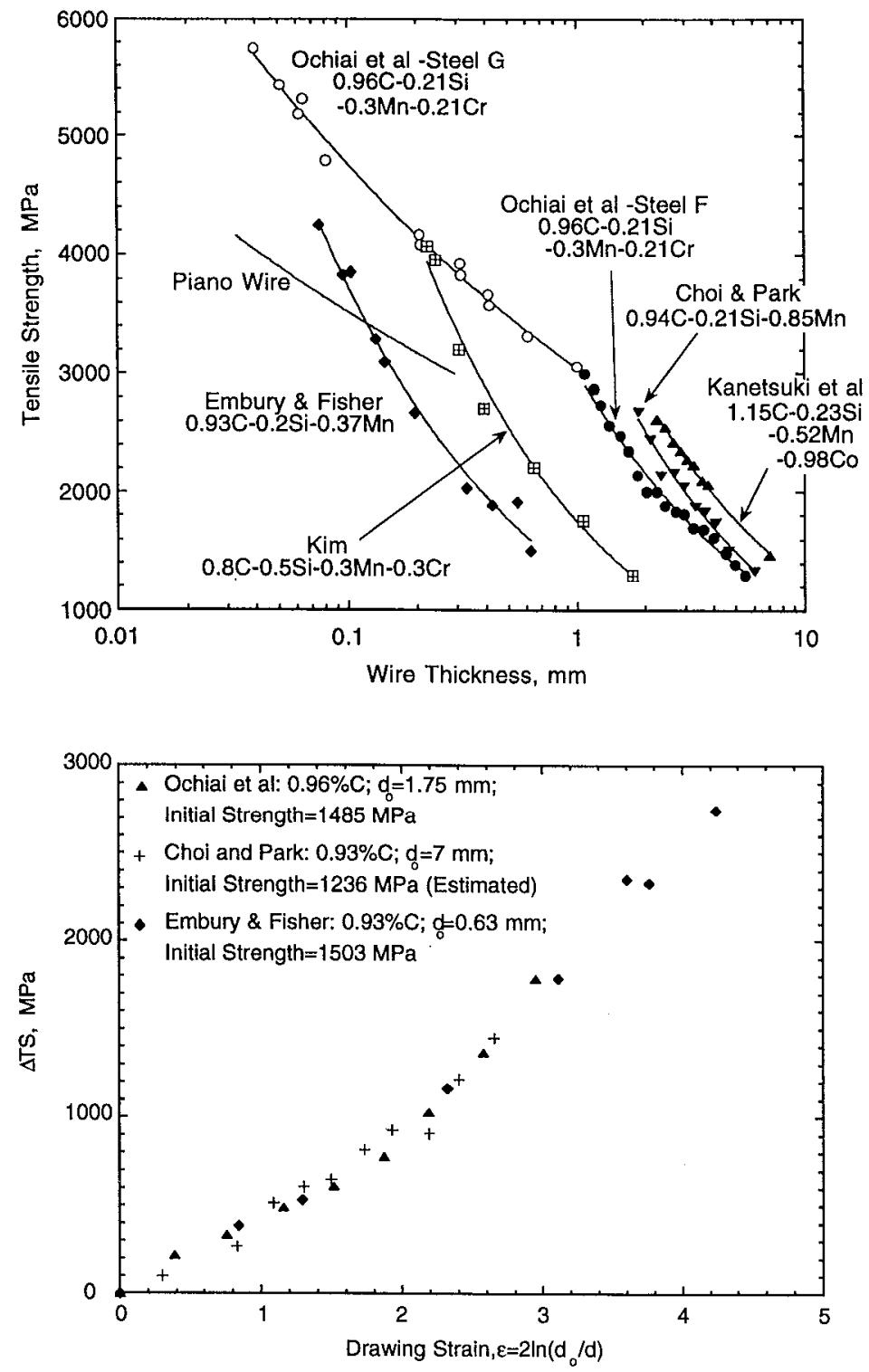

Fig. 3. Tensile strength as a function of wire diameter during wire drawing for eutectoid and hypereutectoid steels.
Fig. 4. Strength increment as a function of wire drawing strain in hypereutectoid steels with similar composition.

Embury and Fisher (6) have studied the principal strengthening mechanisms resulting from cold wire drawing in a Fe- $.93 \mathrm{C}-2 \mathrm{Si}-.37 \mathrm{Mn}$ wire. As discussed above, wirc drawing develops a stable, cellular substructure consisting of narrow, oriented dislocation cells which are the dominant source of strengthening in these materials. In Fig. 5, the variation of stress with cell size (measured normal to the drawing axis) is shown. The wire drawing produced very small cell sizes (10 nm and less). The yield strength of the wire was found to vary as the inverse square root of the width $(\lambda)$ of the cells. Thus

$$
\sigma_{\mathrm{y}}=\sigma_{\mathrm{o}}+\mathrm{k}_{\mathrm{y}} \lambda^{-1 / 2}
$$

where $\sigma_{\mathrm{y}}$ is the yield strength, $\sigma_{\mathrm{o}}$ is the strength from all sources other than dislocation cells, and $\mathrm{k}_{\mathrm{y}}$ is a constant. The strengthening in these severely drawn wires with stable substructures resulted from the cell walls acting as barriers to dislocation motion. 


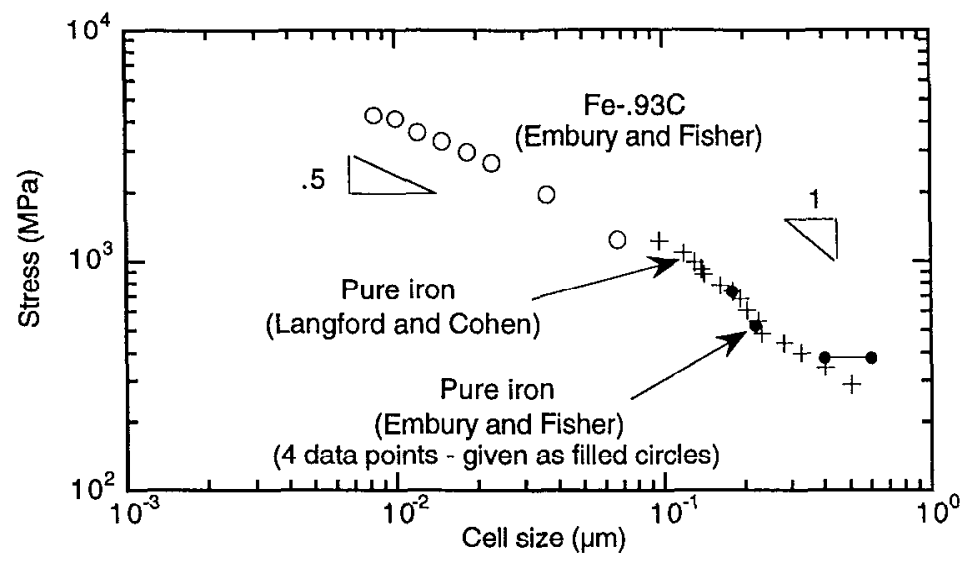

Fig. 5. Stress versus cell size for drawn Fe-.93C (data of Embury and Fisher (6)) and pure iron. The pure iron data is from the two investigations (Embury and Fisher (6) and Langford and Cohen (9)).

The contribution of a stable cellular structure to strengthening has also been studied by Langford and Cohen (9) for pure iron. In contrast to the work of Embury and Fisher, the yield strength was found to vary as an inverse linear function of the dislocation cell size $\left(\lambda^{-1}\right)$. The dependence of flow stress on $\lambda^{-1}$ was theorized to result from the work of deformation required to generate the length of dislocation line necessary to produce the imposed deformation. A comparison of the Embury and Fisher data on a Fe-.93C steel (which showed that strength varied as $\lambda^{-1 / 2}$ ) and the Langford and Cohen data on pure iron (which showed that strength varied as $\lambda^{-1}$ ) is shown in Fig. 5. Clearly different slopes are appropriate for the two data sets, although there is an overall continuity in the data for the two investigations. It is important to note, however, that, in addition to the Fe-.93C alloy, Embury and Fisher also studied a commercially pure iron (Ferrovac E) and found that the yield strength varied as $\lambda^{-1 / 2}$. Despite these differences, the results in Fig. 5 suggest a change in the dominant deformation resistance upon decreasing the cell size.

Two observations relative to the strength levels shown in Fig. 5 are relevant to the various mechanisms of strengthening. First, the initial (as heat treated) strength before wire drawing is higher in the hypereutectoid steel than in pure iron. Clearly this difference arises from the strengthening effects of the carbide plates in the pearlitic steel. By analogy with the experimental work of Taleff et al. $(11,12)$, one might expect that the strength of a pearlitic steel results from the sum of strengthening contributions from different barriers to dislocation motion. Thus for a severely worked pearlitic steel,

$$
\sigma_{y}=\left(\sigma_{\mathrm{o}}\right)_{s s}+\sigma_{\text {pearlite }}+\sigma_{\text {colony }}+\sigma_{\text {cell }}
$$

where $\left(\sigma_{\mathrm{o}}\right)_{\text {ss }}, \sigma_{\text {pearlite }}, \sigma_{\text {colony }}$ and $\sigma_{\text {cell }}$ represent the resistance to dislocation motion resulting from solid solution additions $\left(\left(\sigma_{o}\right)_{s s}\right)$, pearlitic plate spacing $\left(\sigma_{\text {pearlite }}\right)$, pearlite colony size $\left(\sigma_{\text {colony }}\right)$ and dislocation cell size $\left(\sigma_{\text {cell }}\right)$. The $\left(\sigma_{\mathrm{o}}\right)_{\mathrm{ss}}, \sigma_{\text {pearlite }}, \sigma_{\text {colony }}$ terms for hypereutectoid steels are given in equation (1). 'The $\sigma_{\text {cell }}$ term is shown as a function of drawing strain in Fig. 4 (assuming in a severely drawn wire that the yield strength equals the tensile strength). The data in Fig. 4 suggests that for severely drawn wire the cell size dominates the strength of the wire, and the pearlite spacing and pearlite colony size are secondary contributors. Furthermore, this view agrees with the continuous nature of the data shown in Fig. 5, which compares a pearlitic structure wire with a totally ferritic structure wire. The $\sigma_{\text {cell }}$ data in Fig. 4 is for a single composition hypereutectoid steel. It is informative to examine the strength increment due to drawing for all the steels shown in Fig. 3. The results are shown in Fig. 6, which shows a good correlation between the incremental increase in strength and the drawing strain. There is some scatter in the data; the 
general trend, however, is that steels with higher carbon content have higher strength increments for a given amount of drawing strain.

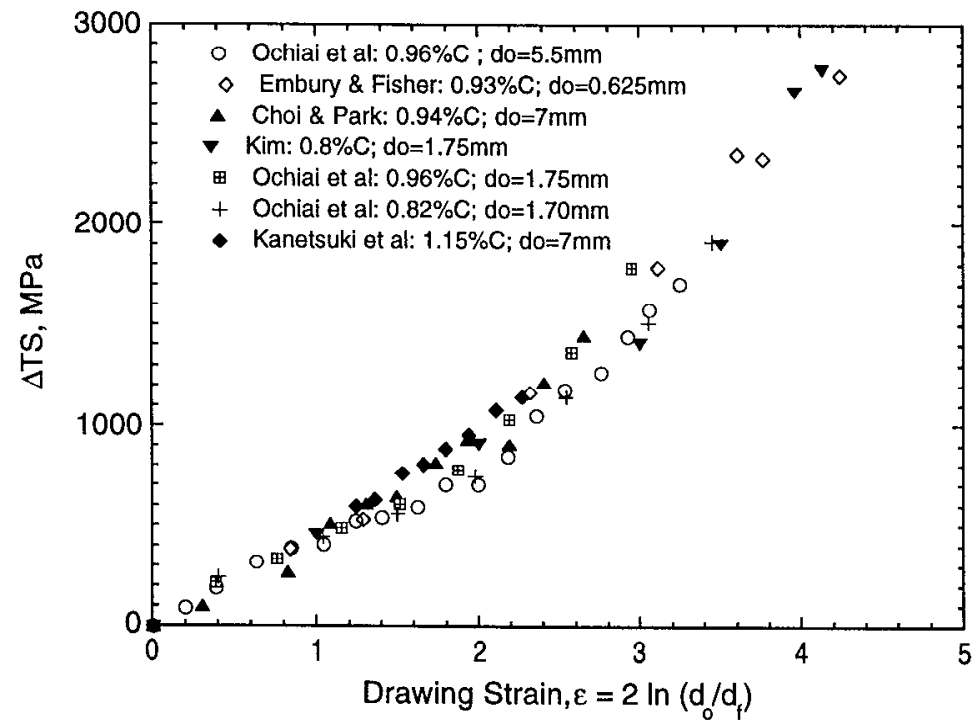

Fig. 6. Strength increment as a function of wire drawing strain for the eutectoid and hypereutectoid steels shown in Fig. 3.

The second observation that can influence the strength levels in Figs. 3, 5 and 6 is the size of the initial cells that form. As noted by Embury and Fisher, who compared dislocation substructures produced in commercially pure iron and $\mathrm{Fe}-.93 \mathrm{C}$ (with both coarse and fine pearlite), the presence of carbide plates produced a smaller initial cell size in the ferrite. In addition, reducing the interlamellar spacing through suitable heat treatment, reduced the initial cell size. Thus, by analogy, increasing the carbon content for a given pearlite colony size will reduce the mean free ferrite path and thus the initial cell size. Since the cell thickness scales with wire diameter during drawing, smaller cell sizes (and higher strengths) are possible for a given drawing strain. These conclusions are consistent with experimental observations by Ochiai $(3,5)$ on eutectoid and hypereutectoid steel wires in that both the as-patented strength and the work hardening rate increased with increasing carbon content.

Comparison with other high strength fibers. The wire strengths described here (e.g. the 5000 $\mathrm{MPa}$ wire strength shown in Fig. 1) represents a very high value - exceeding $20 \%$ of the theoretical cohesive strength of steel. Figure 7 compares the strength of these highly drawn UHCS wires with the strength of bulk materials as well as other fibers that are used as reinforcement in composite materials. The highly drawn UHCS wires are significantly stronger than bulk metals used in structural applications but more importantly the strength of these wires compares favorably with those of other reinforcing fibers such as S-glass, Kevlar-49 and carbon fiber. The figure also shows the cost of the reinforcing fibers; UHCS wire (with an estimated asprocessed cost of $\$ .60$ /pound) is significantly less expensive than other reinforcing fibers. Thus one can expect significant commercial applications with the ultrahigh strength hypereutectoid steel wires described here. 

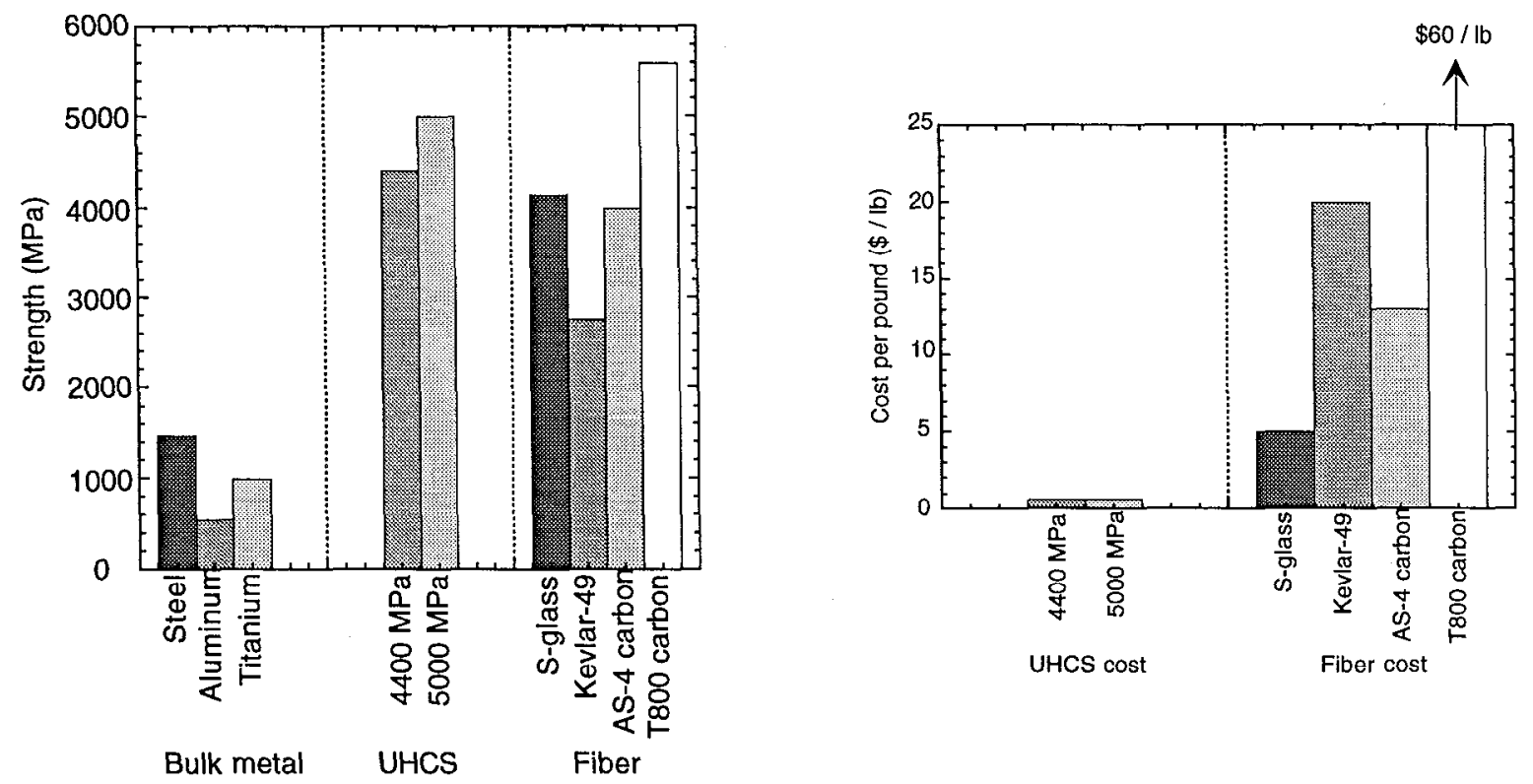

Fig. 7. Comparisons of strength and cost of UHCS wire with other bulk structural metals and reinforcing fibers used in composite materials

\section{Fracture}

Previous work has established that the strength of high carbon and ultrahigh carbon steels is limited by the fracture strength of the carbides. Suppressing fracture is necessary to develop the fine, stable substructures required for achieving very high strengths. Work by Lesuer, Syn and Sherby (18) has established the influence of composition and microstructure on the fracture strength of the carbides. SEM and TEM studies showed that failure in a spheroidized UHCS$1.8 \% \mathrm{C}$ matcrial initiates through tensile scparation of carbide-carbide boundaries in the coarse carbide particles. An example of a carbide particle that was fractured into two parts is shown in the TEM photomicrograph presented in Fig. 8. Fracture is clearly at a grain boundary because both ends of the crack meet at obvious triple points. Diffraction patterns identified that a large misorientation existed between the two separated carbide grains. It was concluded that failure in spheroidized hypereutectoid steels is the result of a crack-nucleation dominated process which is dependent on a critical fracture stress. The fracture strength for UHCS was shown to vary as the inverse square root of the average coarse carbide particle size. The results indicate that fracture of the composite occurs when a critical stress is reached which is solely a function of the average coarse spheroidized carbide particle size (typically found at ferrite matrix grain boundaries). 


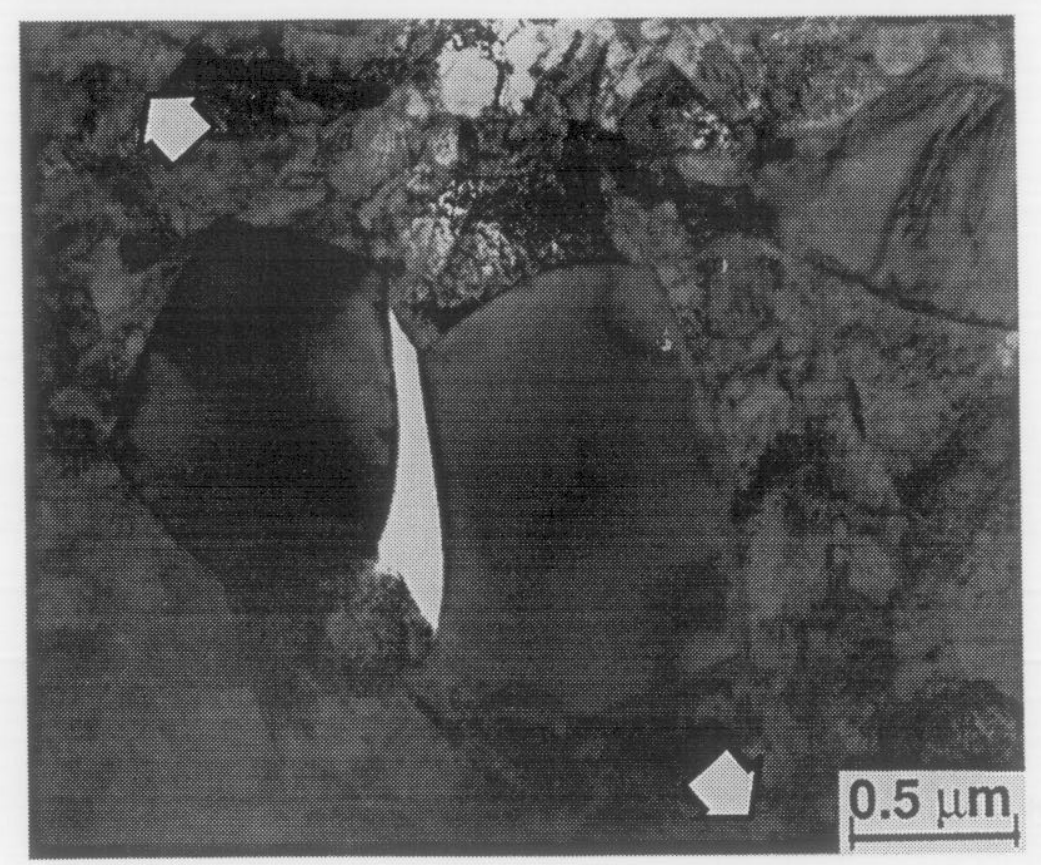

Fig. 8. TEM of a large carbide particle fractured in a UHCS$1.8 \%$ during tensile testing. Tensile axis is indicated with arrows.

Another important variable influencing the fracture strength of hypereutectoid steels is the intrinsic fracture strength of the carbide. In detailed analyses of fracture data for various hypereutectoid steels, Lesuer, Syn and Sherby (18) developed a fracture model based on the concept that the ferrite matrix applies stress to the carbide particle and thus the stress in the ferrite matrix is the driving force for crack initiation at the grain boundaries within the coarse carbides. The authors calculated the ferrite matrix fracture stress by averaging the ferrite stress using upper and lower bound concepts. In order to fulfill the fracture mechanics requirement that the ferrite matrix fracture strength must be zero at infinite carbide (crack) size, Lesuer et al. made the discovery that the strength of the carbide was a function of composition of the hypereutectoid steels studied. This discovery is graphically illustrated in Fig. 9 where three groups are shown according to composition differences. The unalloyed and low alloyed hypereutectoid steels show higher values of carbide strength than the more extensively alloyed steels. It would appear that elements that dissolve in the carbide decrease the grain boundary strength. Thus, it is postulated that chromium and aluminum, which dissolve in iron carbide and distort the carbide lattice (or form carbide of a different structure), decrease the grain boundary carbide strength. On the other hand, silicon, which does not dissolve in the carbide, does not influence the grain boundary carbide strength (material of Le Roy et al. (19)). Manganese is known to produce an $\mathrm{M}_{3} \mathrm{C}$ type carbide, as does iron, and therefore may behave in a indistinguishable way from iron in influencing the grain boundary strength. 


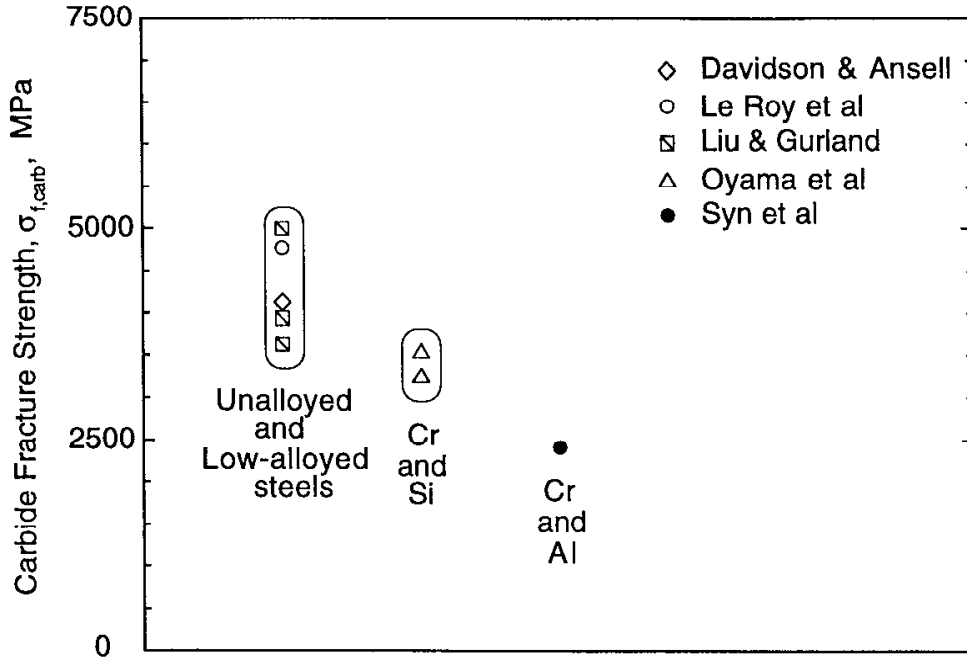

Fig.9. Predicted carbide fracture strength as a function of composition for spheroidized hypereutectoid steels.

\section{Summary and Concluding Remarks}

This paper has reviewed the processing, microstructure evolution and resulting strength of UHCS subjected to severe plastic deformation during wire drawing. Mechanisms of strengthening and fracture have been discussed. Important conclusions are as follows.

- Very high strengths are possible in hypereutectoid steel wire. At $1.8 \% \mathrm{C}$, hypereutectoid steel wires are projected to have a strength approaching $6000 \mathrm{MPa}$.

- Severe plastic deformation during wire drawing of hypereutectoid steels results in considerable alignment of the pearlite plates and the development of a substructure that resists dynamic recovery.

- The yield strength in hypereutectoid steels has been shown to result from additive strengthening contributions from solid solution additions, pearlite spacing, pearlite colony size and dislocation cell size. For severely drawn wire, the strengthening due to dislocation cells can dominate the strength of the wire. The strength varies as the inverse square root of the cell size.

- Increasing the carbon content reduces the mean free ferrite path in the as-patented wire and the initial cell size developed during drawing. This results in a higher flow stress in the aspatented wire and a higher work hardening ratc.

- Fracture was found to initiate through tensile separation of carbide-carbide boundaries in coarse carbide particles. The fracture strength is a function of the size of coarse carbides and of composition.

- Achieving high strength requires a) eliminating the continuous carbide network that can form during cooling from temperatures in the austenite phase field, b) a starting microstruclure of fine pearlite, c) development of a stable dislocation substructure within the ferrite and d) avoiding fracture. 


\section{Acknowledgments}

This work was performed under the auspices of the U. S. Department of Energy by Lawrence Livermore National Laboratory under contract No. W-7405-ENG-48. Support was provided in part by the Laboratory Directed Research and Development Program.

\section{References}

1. D. R. Lesuer, C. K. Syn, A. Goldberg, J. Wadsworth, O. D. Sherby, JOM 45, 40-45 (1993).

2. I. Ochiai, H. Ohba, Y. Yohji, M. Nagumo, Tetsu-to-Hagane 74, 1625-1632 (1988).

3. I. Ochiai, S. Nishida, H. Ohba, A. Kawana, Tetsu-to-Hagane (J. of Iron and Steel Inst. of Japan) 79, 89-95 (1993).

4. I. Ochiai, S. Nishida, H. Tashiro, Wire Journal International 26, 50-61 (1993).

5. I. Ochiai, S. Nishida, H. Ohba, O. Serikawa, H. Takahashi, Materia Japan (Bulletin of Japan Inst. of Metals) 33, 444-446 (1994).

6. J. D. Embury, R. M. Fisher, Acta Metallurgica 14, 147-159 (1966).

7. J. D. Embury, A. S. Keh, R. M. Fisher, Transactions of the Metallurgical Soceity of AIME 236, 1252 - 1260 (1966).

8. G. Langford, Metallurgical Transactions 1, 465 - 477 (1970).

9. G. Langford, M. Cohen, Transactions ASM 62, 623-638 (1969).

10. J. Languillaume, G. Kapelski, B. Baudelet, Acta Materiala 45, 1201 - 1212 (1997).

11. E. M. Taleff, C. K. Syn, D. R. Lesuer, O. D. Sherby, in Thermomechanical Processing and Mechanical Properties of Hypereutectoid Steels and Cast Irons D. R. Lesuer, C. K. Syn, O. D. Sherby, Eds. (TMS, Warrendale, PA, 1997).

12. E. M. Taleff, C. K. Syn, D. R. Lesuer, O. D. Sherby, Metallurgical Transactions 27A, 111-120 (1996).

13. D. R. Lesuer, C. K. Syn, O. D. Sherby, D. K. Kim, Eds., Processing and Mechanical Behavior of Hypereutectoid Steel Wire (TMS, Warrendale, PA, 1996).

14. D. R. Lesuer, C. K. Syn, O. D. Sherby, D. K. Kin, W. D. Whittenberger, in Thermomechanical Processing and Mechanical Properties of Hypereutectoid Steels and Cast Irons D. R. Lesuer, C. K. Syn, O. D. Sherby, Eds. (TMS, Warrendale, PA, 1997) pp. 175-188.

15. Y. Kanetsuki, N. Ibaraki, S. Ashida, Iron and Steel Inst. of Japan International 31, 304311 (1991).

16. D. K. Kim, R. M. Shemenski, . (1992).

17. H. C. Choi, K. T. Park, Scripta Materialia 34, 857-862 (1996).

18. D. R. Lesuer, C. K. Syn, O. D. Sherby, Acta Metallrugica et Materialia 43, 3827-3835 (1995).

19. G. LeRoy, J. D. Embury, G. Edward, M. F. Ashby, Acta Metallurgica 29, 1509-1522 (1981). 